\title{
Urbanization in Ethiopia: Expropriation Process and Rehabilitation Mechanism of Evicted Peri-Urban Farmers (Policies and Practices)
}

Idris Mohammed*, Abdella Kosa and Nuredin Juhar

College of Business and Economics, Debre Berhan University, Ethiopia

\begin{abstract}
Urbanization programme in Ethiopia is neither participatory nor supportive to farmers in periphery, and thus has negative impact on people livelihood and highly affects the livelihood of poor people by diminishing the natural resource available to them. The municipality has provided cash compensation for affected rural people. However, monetary compensation is not an appropriate mechanism to rehabilitate an affected people and minimal and seems inadequate. The aim of the study was to assess policy and practice of land expropriation process and rehabilitation mechanism of evicted peri-urban farmers as the result of urban expansion to peripheral areas in Ethiopia. Primary data were collected from 200 peri-urban evicted farmers through questionnaires and 30 conducted interview with municipality officials. As the findings of the study shows that the reason for eviction of peri-urban farmers in Ethiopia are industries, urban dwellers residential house, public projects, private investments, NGO projects, Recreational sites and industrial parks. Peri-urban land are potential areas of interest, most stakeholders are tied to together confidentially for malpractices. Peri-urban farmers have the complaints on property valuation, amount of compensation, survival strategies and on implementation of policies, however, poor response. The rehabilitation practice which most municipalities now applying are mostly monetary compensation but rare practice of income capitalization. The practical implications that should be applied are use combination of rehabilitation mechanism, apply standardized land expropriation process, apply proper grievance handling mechanism and create enabling environment for peri-urban farmers.
\end{abstract}

Keywords: Expropriation; Rehabilitation; Grievance; Policy; Practice

\section{Introduction}

\section{Back ground of the study}

The urban expansion to its surrounding peripheral area consumes large amount of farmland throughout the world. For instance, due to rapid urbanization china loses close to one million hectares of cultivable farm land each year to accommodate various demands such as construction of roads, industrial buildings, and commercial centers and for residential purposes [1]. Urban expansion creates numerous challenges that may be beyond the capabilities of the economies of developing nations including the creation of job opportunities and provision of basic needs [2]. Unlike the situation in the developed countries at comparable stages of development, the process of urbanization in the Third World Countries appears to be more a function of rural push factors than the urban pull factors [3].

The urban expansion in Ethiopia is believed to capture less the view of neighborhoods that were forced to leave their land and property. Urbanization programme in Ethiopia is neither participatory nor supportive to farmers in periphery, and thus has negative impact on people livelihood where women and youth are the major victims. Peri- urban area the peripheries which are administered by the city administration of the area of Kebele to which urban settlements are immediately extending to rural settlements and changing the way of life from agriculture to non-agriculture. Due to diverse land uses, most population of peri-urban areas are original residents, farmers, migrant residents, recreational land users, industrial users, investors and speculators, developers and builders [4]. Moreover, the nonfarm based economic sector was not developed to absorb displaced farming communities. Therefore, the non-integrative type of urban development induced displacement disturbs on those marginalized rural communities and forces them to live in poverty, food insecure and hopelessness [5]. Little attention has been given for the periurban interface, due to they are neither being under the control of urban authorities nor under the control of rural authorities. Yet only a few of people are made rich, while the majority is excluded from the opportunities that peri-urbanisms.

Hence, urbanization disproportionately affects the livelihood of poor people by diminishing the natural resource available to them. In order to mitigate the problem, the municipality of the town has so far promoted the option of cash compensation for the development of affected rural people. However, monetary compensation suggested by many people that it is not an appropriate mechanism to rehabilitate an affected people and even the payment of cash are minimal and rate of compensation seems inadequate [6]. If expansion urban areas and industrial complexes continue in this way, we can expect that large number of displaced household people will soon face considerable problems. The expansion of urbanization also created numerous opportunities as well as challenges for surrounding farming communities. Urbanization opportunities include employment, access to urban services and urban-rural linkages [7]. But rural communities around the city faced economic challenges [8]. If the expansions of urban settlement continue to the surrounding rural areas of Ethiopia, there is high probability that many rural people will soon face a crisis in their livelihood and will be exposed to economic deprivations. Since

${ }^{*}$ Corresponding author: Idris Mohammed, Lecturer in College of Business and Economics, Debre Berhan University, Ethiopia, Tel: +251926757302; E-mail idrisko21@yahoo.com

Received August 11, 2017; Accepted August 21, 2017; Published August 22, 2017

Citation: Mohammed I, Kosa A, Juhar N (2017) Urbanization in Ethiopia: Expropriation Process and Rehabilitation Mechanism of Evicted Peri-Urban Farmers (Policies and Practices). Int J Econ Manag Sci 6: 451. doi: 10.4172/2162 6359.1000451

Copyright: (๑) 2017 Mohammed I. This is an open-access article distributed under the terms of the Creative Commons Attribution License, which permits unrestricted use, distribution, and reproduction in any medium, provided the original author and source are credited. 
peri-urban land is potential areas of interest, there is high probability for arising potential conflicts. The compensation which is paid for displaced farmers is not fair and insignificant. Monetary compensation is also not best mechanism to rehabilitate evicted farmers. Monetary compensation cannot solve their economic problems. Societies saving habits are also poor. After they collect monetary compensation, they consume that amount and spend on non-planned and non-productive activities. Their survival strategies are not properly supported by urban administrators. Peri-urban farmers' livelihood only dependent on agricultural before expropriation. After they were evicted from their land, they are hopeless and live in poor economic conditions. Most of the displaced peri urban farmers are living in economic poverty which need due attentions from all stakeholders.

\section{Research questions}

Based on the above stated problems, the study will answers the following research questions.

What are the reasons for land expropriation of peri-urban farmers due to urbanization in Amhara Regional State?

What are the procedures followed of Land Expropriation due to urban expansion in Amhara Regional State?

What are the practices of rehabilitation strategies for evicted peri-urban Farmers and good rehabilitation mechanism that helps to support mutual benefits of urban and rural dwellers?

What are the policy and practice grievance handling mechanism and municipality intervention on land expropriation of peri-urban farmers?

\section{Objectives of the Study}

The general objective of the study is to assess policy and practice of land expropriation process and rehabilitation mechanism of evicted peri-urban farmers as the result of urban expansion to peripheral areas in Ethiopia.

The specific objectives are:

To identify the reasons for land expropriation of peri-urban farmers due to urbanization in Amhara Regional State?

- To explore the procedures followed for Land Expropriation due to urban expansion in Amhara Regional State.

To find out the practice of rehabilitation strategies for evicted peri-urban Farmers and good rehabilitation mechanism that helps to support mutual benefits of urban and rural dwellers?

- To assess policy and practice grievance handling mechanism and municipality intervention on land expropriation of peri-urban farmers.

\section{Scope of the study}

The study was focused on policy and practice of expropriation process and rehabilitation mechanism of evicted farmers due to urban expansion in to peripheral areas in Ethiopia, specifically in Amhara regional state. The study more focused on eastern part of Amhara regional state. From eastern part of Amhara regional state, five municipalities that are highly vulnerable to negative externalities of urbanization and fast urbanized cities were selected. Those urban areas are Debre Berhan, Dessie, Kombolcha, Shoa Robbit and Woldia. The issues analyzed were policy, practice, expropriation process, rehabilitation mechanism and complaints. The study more focused on land expropriation process and rehabilitation mechanism of evicted peri-urban farmers. The researchers assessed land expropriation process and rehabilitation mechanism from 2006 to 2016.

\section{Research Methodology}

The research is descriptive type. Qualitative and quantitative approach was used. To support secondary data, primary data were collected through survey method on policy, actual practice, and expropriation process and rehabilitation mechanism of evicted periurban farmers. Those data were collected from both primary and secondary sources. The primary data were collected from evicted periurban farmers and municipality officials of sampled municipalities. Secondary data were collected from the relevant literatures and published documents. Multi stage sampling technique was adopted. In the first stage, eastern part of Amhara region was selected because of high vulnerability to the identified problem. In the second stage, fast urbanized cities in eastern Amhara regional state were selected. Those towns are Debre Berhan, Kombolcha, Dessie, Shoa Robbit and Woldia. In the study, evicted Households and respected municipality officials were taken as sampled respondents.

Primarily data were collected through the combination of key informant and personal interviews and questionnaires. Secondary data were collected from published government reports, books, articles, and government proclamation. Survey methods were administered to collect information from farmers who were displaced from their land for urban land uses mainly for industrial, residential and investment purposes. The survey were administrated at the peri-urban areas where most farmers have already been dispossessed their land and areas where the number of farmers were evicted in larger $\&$ the problem is more critical. According to information obtained from Amhara Regional state, peri-urban Farmers of Debre Berhan, Kombolcha, Dessie, Shoa Robbit and Woldia areas are more vulnerable to be evicted from their land than other urban areas of eastern part of Amhara. Large numbers of investors are attracted at those areas, potential areas for public sector projects, potential areas for industries and investment. Through snowballing non random sampling, researchers were contacted with displaced farmers who were move to unknown location. Urban land administration knows the permanent location of evicted farmers and who has housing plot and data were collected from them through convenience sampling.

Total 200 questionnaires were distributed and collected from periurban farmers. For the purpose of collecting sufficient data from target respondents 30 key informant interviews were conducted with all sampled municipalities. Grand total target respondents for the study were 230 respondents from all sampled municipalities of Amhara regional state. Total 200 survey questionnaires were distributed, administered and collected from evicted peri-urban farmers of study areas were under consideration. Both open and close ended questions were included in the questionnaires to capture more information on research gap. From evicted peri-urban farmers of Debre Berhan municipality, 37 questionnaires were collected, 39 questionnaires were collected from evicted peri-urban farmers of Dessie municipality, 50 questionnaires were collected from evicted farmers of Kombolcha municipality, 38 questionnaires from Shoa Robbit and 36 questionnaires were collected from peri urban evicted farmers of Woldia municipality. Those respondents are evicted farmers due urban dwellers residential, industrial and investment other than industry. Those municipality officials who provide data on the study urban administrators, experts, urban land management and investment office workers. Six interviews 
were conducted with each municipalities of Amhara regional totally 30 $\left(6^{*} 5=30\right)$ conducted interviews.

Sometimes a retrospective data collection method was used while respondents were asked to provide present information and remember and reconstruct significant events and /or aspects of their assets, strategies and poverty. To obtain relevant and sufficient information and to administer key informants around the issue, check list were prepared. The check list were include issues like challenges and scenarios derived from horizontal expansion of the town over the farmer's land, compensation package, involvement of community in the programme \& future perception on expansion. The lists of the affected households were collected then generated from roasters of urban administration and formed sampling frame. These sampling frames were determined purposively through quota sampling. Prior to analysis, completed questionnaires were coded, inputted and organized. A coding system of some variables was prepared at the time of the questionnaire design. After the completion of coding, all valid questionnaires were inputted in a coherent format of SPSS database and version 20 SPSS were used. Survey data were interpreted by using descriptive (mean, standard deviation, minimum and maximum values) and inferential statistics (correlation and regression analysis). Secondary data that were obtained from various data sources were organized and analyzed to compliment the survey results. Those secondary data were analyzed through content analysis.

\section{Results and Discussion}

The analysis was made based on 200 collected questionnaires from peri-urban evicted farmers and 30 conducted interview with municipality officials. Policies and Proclamations which were adopted by government at different time such as Proclamation No. 455/2005 (Expropriation of Landholdings for public Purposes and Payment of Compensation Proclamation) which is adopted at national level, Proclamation No. 721/2011 (Urban Lands Lease Holding Proclamation) which was adopted at national level FDRE, Council of Ministers Regulations No. 135/2007 were assessed concerning urban policy and rehabilitation strategies.

\section{Reason for eviction of farmers in peri-urban areas}

As data collected from respondents of sampled municipalities' shows, there are different reasons for evictions of peri-urban farmers from their home lands. The demand for peri-urban land is highly increases in fast pace for different purposes such as for manufacturing industries (textile, brewery, flour factories), urban dwellers residential house, public projects (roads, telecommunications, banks, elementary and high schools, health stations and stadiums), local governmental buildings, private investments projects, non-governmental organization projects, Recreational sites, cooperatives and unions projects and industrial parks. The reason for eviction of peri-urban farmers in Amhara regional state in sampled municipalities were summarized and presented in the following Figure 1.
In general, the main reason of eviction in most municipalities of Amhara regional state is due to urbanization expanded to peripheral areas. When urban expanded to peripheral areas, the demand for land increases. Different stakeholders are competing to get the land for different purposes.

\section{Procedures of Land Expropriation Process}

According to Amhara Regional State Proclamation No. 133/2006, 2006 [9], the authority of expropriate rural land from any holder or user for the public service by paying proper compensation in advance. Where the land expropriation activity is directly related with the development of the surrounding society, the case shall be submitted to the kebele people for discussion and get majority vote, therein, before it is decided by the Woreda branch office of the Authority to expropriate land for public service (ibid). As it is presented in Table 1, the actual practice of farmers' expropriation process does not follow guiding principles and standardized procedure. However, conducted interview with municipality officials revealed that they follow standardized, well prepared and participatory procedure during land expropriation. The actual practice of land expropriation in sampled municipalities of Amhara regional state is presented in the following Table 1.

As the above Table 1 showed that before target farmers were evicted from their homeland, the properties which are situated on the land is valued by expert. In some circumstance they apply laws and policies as the ground rule then valued the property situated on the expropriated land.

In other cases, they give high priority to satisfy their personal interest rather than applying urban policies and proclamation. Due to this fact, most experts who are assigned for valuation of property which is situated on expropriated land are performing malpractices. Since urban and peri-urban land are potential areas of interest, most stakeholders are tied to together confidentially for satisfying their personal interest rather than doing legal, moral and reasonable practices. As conducted interview suggested, controlling and monitoring of municipality and higher officials from zonal administration, regional and Federal to review progress and practices of expert is also poor. So they have a chance to make confidential deal of malpractices with others stakeholders to satisfy their personal interest. As the above table revealed, most evicted farmers are expropriated without their mutual consent. They complaint and appeal to the regular court. The judge decision is considered as the final decision then peri-urban farmers are evicted from their home land. Since valuation by expert is based on personal judgment (subjective) of an expert, they are few properties which are considered for valuation and improper measurements. Periurban farmers have the complaints on property valuation, amount of compensation, municipality interventions, survival strategies and gap on implementation of policies. On one hand, they are not interested to lose their indigenous homeland. On the other hand, expropriation process and rehabilitation strategies are not to protect interest of peri-urban farmers. Lack of proper monitoring and follow up from

\begin{tabular}{|c|c|c|c|c|c|c|c|}
\hline No. & $\begin{array}{l}\text { Procedures in land expropriation process in } \\
\text { Amhara regional state }\end{array}$ & Respondents & Minimum & Maximum & Mean & $\begin{array}{c}\text { Std. } \\
\text { Deviation }\end{array}$ & $\begin{array}{c}\text { Pearson correlation } \\
\text { coefficient }\end{array}$ \\
\hline A. & Mutual Consent and understanding reached & 200 & 1 & 5 & 2.48 & 0.99 & 0.225 \\
\hline B. & Property Valuation by expert based on consent & 200 & 1 & 5 & 3.27 & 1.37 & 0.167 \\
\hline C. & Complaint on Property Valuation & 200 & 1 & 5 & 4 & 0.9 & 0.358 \\
\hline \multirow[t]{2}{*}{ D. } & $\begin{array}{c}\text { Evaluation of Complaint and Provide a } \\
\text { Response }\end{array}$ & 200 & 1 & 5 & 2.74 & 1.3 & 0.329 \\
\hline & Valid N (list wise) & 200 & & & & & \\
\hline
\end{tabular}

Table 1: Procedures of land expropriation in Amhara Regional State. 


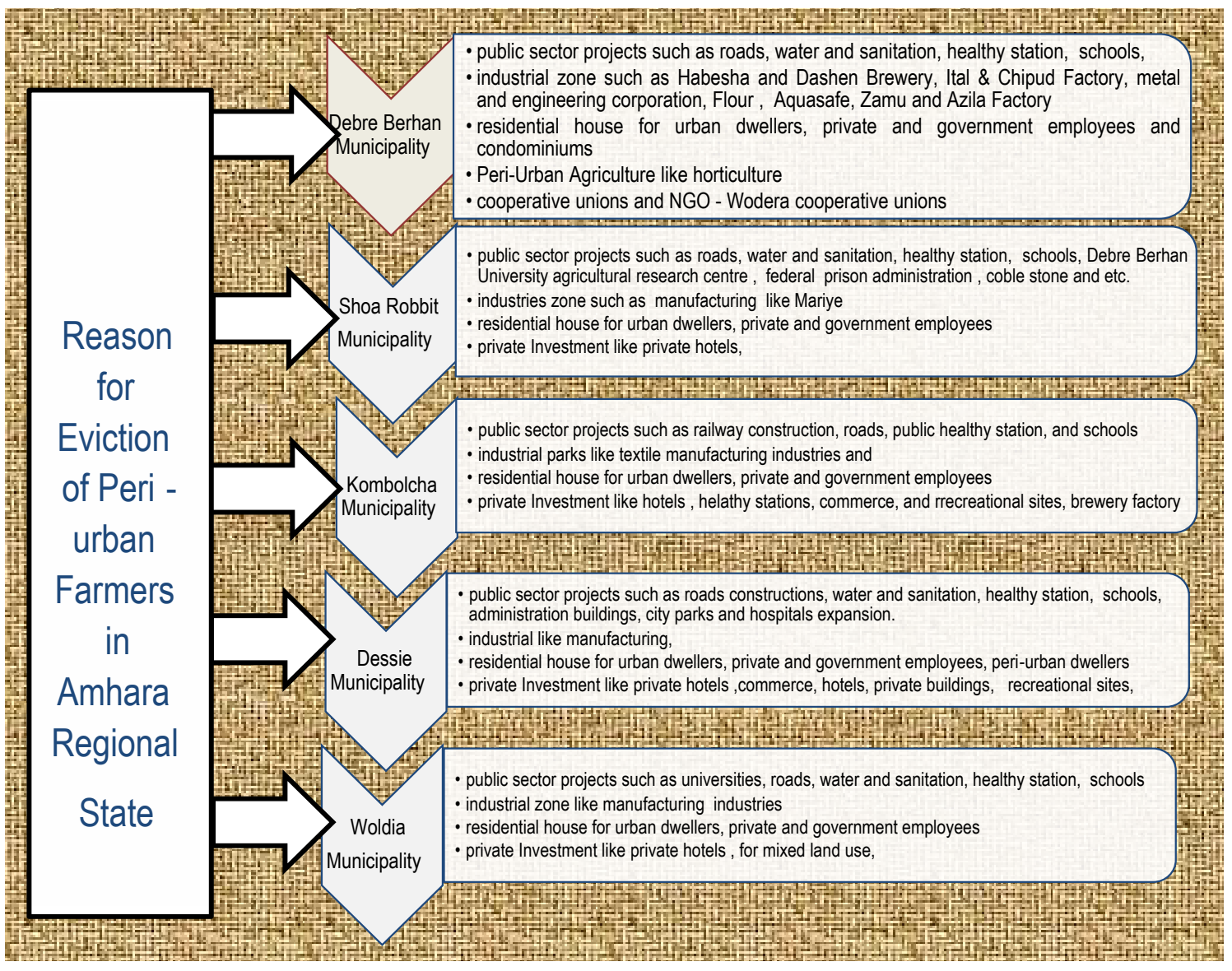

Figure 1: Reasons for evictions of peri-urban farmers in Amhara Regional State from 1999-2009.

higher officials and corruptions of municipality officials affect the livelihood of peri-urban farmers. So the cumulative effect of forcedly eviction, lack of proper monitoring and follow up from municipality and higher officials, insignificant compensation, poor treatment during expropriation process, vulnerability to corruption and nonparticipatory urban planning and policies creates public dis-trust and unsolved grievance in the peri-urban areas of Amhara regional states.

As the general concept, development without participatory and beneficiary of peri-urban farmers cannot be sustainable at local and regional level. If the municipality follows standardized, fair, impartial, well-known and well-structured procedures for land expropriation, the probability of creating gap on implementation of policy and proclamation will be too low. As data collected from the farmers, they do not follow standardized procedures. However, as the principle and formality, all municipalities posted standardized procedures of land expropriation during eviction of farmers' communities from their land. But the practice on the ground does not show properly follow standardized procedure. Example, Kombolcha municipality officials argued that they do not undertake socio-economic impact assessment before expropriation begins. However Dessie municipality, critically assess expropriation of land on socio economic impacts of peri-urban farmers. Showa Robbit municipality, they provide consultation then property valuation then provide compensation finally evict farmers from the land. In Debre Berhan municipality, through positively contact with peri-urban farmers then provide consultation then complaint if any, then property valuation by a group of experts then provide compensation finally eviction process will begin.

The General and standardized procedures of land expropriation which most municipalities in Amhara regional state prepared as formalities are presented in Figure 2.

But the main challenge that all municipality faces are putting expropriation procedures on the board as the guideline, however, unfollowed and improper practice during actual practice.

\section{Valuation of property situated on expropriated land}

According to FDRE Proclamation No. 455/2005, 2005), art 7 [10], the amount of compensation for property situated on the expropriated land shall be determined on the basis of replacement cost of the property (ibid, art. 7). Replacement cost is rehabilitating the cost of property which was situated on expropriated land. This indicates by using replacement cost, the properties (fixed assets), agricultural products (like cereal crops), and plants (trees), fence, toilet and etc. will be recovered. So article 7 of this proclamation argued that compensation will be calculated through replacement cost method and cover capital and labor expended on expropriated land. The income that will be generated from the expropriated land will be considered, however, it is fixed not considering market values. The interview conducted with sampled municipalities officials shows valuation of property which are situated on the expropriated land is based the fixed ratio of 1997 E.C. does not consider current market values. 


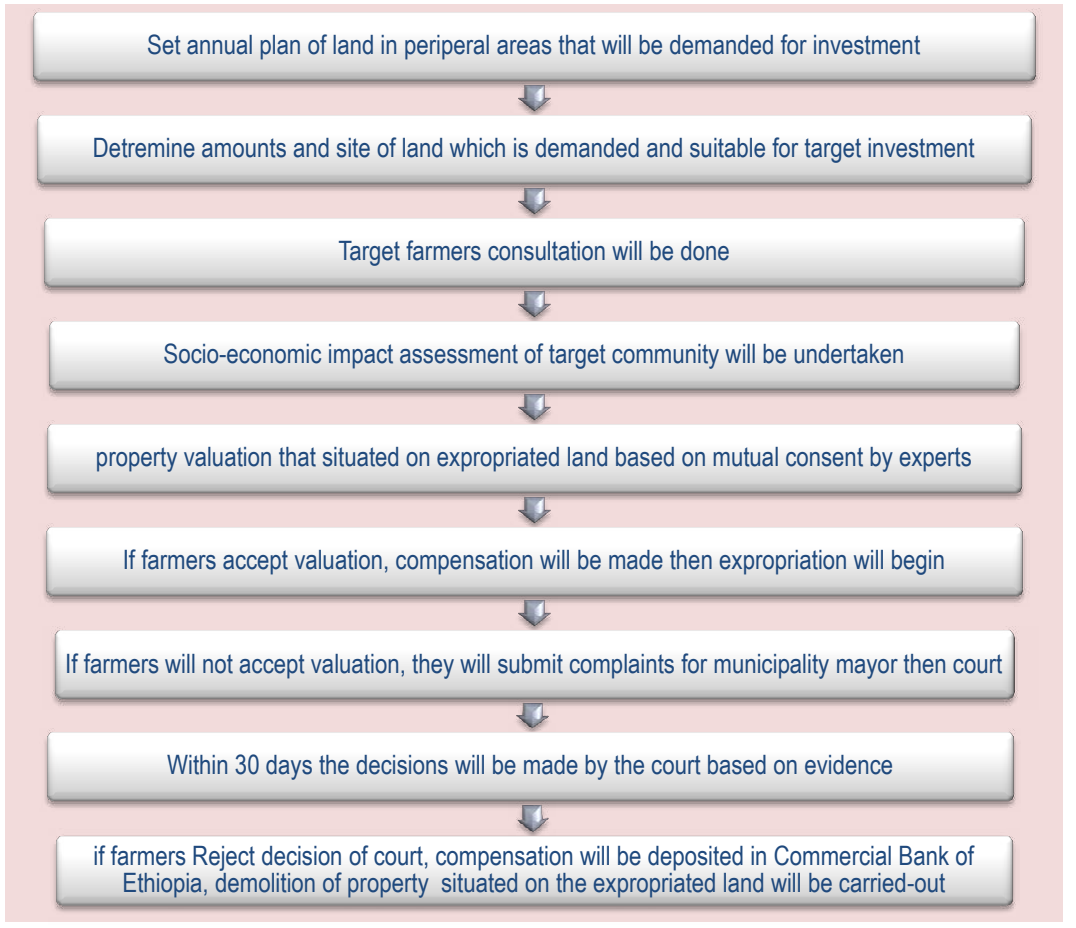

Figure 2: The General and Standardized procedures during land expropriation in Amhara regional state.

According to (FDRE Proclamation No. 455/2005, 2005), art 9 [11], the valuation of property situated on land to be expropriated shall be carried out by certified private or public institutions or individual consultants on the basis of valuation formula adopted at the national level. Art. 10 of this proclamation suggested that property which is available on the land will be valued by committees. Where the land to be expropriated is located in a rural area, the property situated thereon shall be valued by a committee of not more than five experts having the relevant qualification and to be designated by the woreda administration (sub-art. 1). This proclamation also suggests valuation of property which is situated on the expropriated land will be done by experts who have a duty in each urban area. This proclamation also support and determine the qualification of experts. Accordingly, experts have at least related educational qualification of background of urban planning, cost management and property valuation.

Valuation of property will be calculated by a group of experts. This is a good opportunity to bring fairness and reduce malpractices. The general concepts of this proclamation deals with valuation of the property will be conducted through standardized formula which is adopted at national level, valuation will be conducted by a group of experts (at least five experts), and they are organized by municipality or woreda administration based on their related education qualifications and experiences and have own well identified procedures. According to (Amhara regional state proclamation No. 133/2006, 2006), even though, the compensation payer is government, private organization, community or other body, the calculating formula for compensation shall be the same. However, this proclamation has the limitations of inconsideration of location advantages, rigidity of formula and not considering market price of property.

The current practice on the ground in different municipalities of Amhara regional state shows that there are no full implementation of this policy as questionnaires collected and interview conducted with peri-urban farmers suggested. Those experts who are assigned for this positions are performing mal practices (like corruptions and bribes), valuation of property by few experts and unqualified experts are available in some municipalities (no right person at the right positions). They are not providing enough justification for peri-urban farmers during property valuation on fairness and reasonability of amounts of money allocated for compensation. As the respondents of Dessie municipalities suggest Valuation property situated on the land is calculated based on 2003 E.C ratio, however, in Kombolcha municipality valuation of property situated on the expropriated land is in a consideration of market values. However, in Shoa Robbit municipality Valuation formula for property which is situated on expropriated land is based on 1997 E.C. ratio. This indicates they are not following the same procedure and valuation mechanism. If they do not consider market value of property, they are not considering inflation and time value of money. In most municipalities, local government (municipality officials) pays monetary compensation and owned land by government. In a valuation practice, they consider income that indigenous peri-urban farmers will earn from the land. In all sampled municipalities, if expropriated land is Arable land (grass and crop land), valuation of property will consider income capitalization (income of 10 years will be calculated and paid). However, measurement of property which is situated on the expropriated land is depending on experts that are subjective and differ from expert to expert.

In sampled municipalities of Amhara regional state, the Sample of properties that should be considered and valued during expropriations are Palm trees, Mango trees, Main residential house, Toilet, Kitchen, large Weira, Baharzef, Card board fence, Metal fence, Banana trees, Cassava trees, orange trees and all properties that can generate income for households will be considered and valued. Agricultural products 
such as barley, wheat, mung-bean, and fruits and vegetables and horticulture will be considered and valued during income capitalization.

\section{Rehabilitation strategies for evicted peri-urban farmers}

According to (FDRE Proclamation No. 455/2005, 2005) art 2, Compensation which is paid for evicted farmers from their land is the payment to be made in cash or in kind or in both to a person for his property situated on his expropriated landholding. This proclamation argued that evicted farmers/households will be compensated in cash, in kind or both in cash and in kind. The practice of rehabilitation of evicted farmers due to urban expansion in peripheral areas in Amhara regional state is neither fully implementation of national/regional policy nor fully protection of evicted farmers interest. At some time, they will pay full monetary compensation and at others time, monetary compensation plus displacement compensation. The rehabilitation mechanisms that are followed and practiced by sampled municipalities were presented in the following Table 2 .

Monetary compensation: According to (FDRE Proclamation No. $455 / 2005,2005)$ art.,7), argued that compensation payment may not, in any way, be less than the current cost of constructing a single room low cost house in accordance with the standard set by the concerned region. As above Table 2 shows that monetary compensation is mostly practiced to rehabilitate evicted farmers but it is no best mechanism as different authors suggest [12-14]. The formula for calculating the amount of compensation payable in accordance with the (FDRE Proclamation No. 455/2005, 2005) and (FDRE Council of Ministers Regulations No. 135/2007, 2007) [15] were presented as;

Compensation for building=cost of construction + cost of permanent improvement on land the amount refundable money for the remaining term lease contract.

Compensation for crops=the total area of the land (in $\left.M^{2}\right) \times$ value of the crop per kilo gram $x$ the amount of crop to be obtained per $M^{2}+$ cost of permanent improvement on land.

Compensation for unripe Perennial Crops=number of plants (legs) $x$ cost incurred to grow an individual plant + cost of permanent improvement on land.

Compensation for ripe annual yield of the Perennial Crops=Perennial crops (in KG) X current price to produce of the perennial] crops + cost of permanent improvement on land.

Compensation for relocated Property=cost of removal + cost of transferring+ cost of Reinstallation.

Compensation for protected grass=area covered by the grass per square meter $X$ the current market price of the grass per square meter.
Shoa Robbit Municipality, in 2016, for monetary compensation 6,351,001 birr was planned and allocated, then (99\%) of allocated budget for compensation was paid. In Debre Berhan Municipality, in 2017, birr $11,147,557$ is planned and allocated but paid amount is $76 \%$ within 9 months. In Dessie municipality, more than 15 million is planned and allocated for monetary compensation, however, municipality paid more than 18 million birr. However, municipality officials and farmers are in opposite extreme point concerning rehabilitation through monetary compensation. Municipality officials want to create enabling environment for private investors through expropriation of indigenous peri-urban farmers through monetary compensation mechanism. Then urbanization expanded in to peripheral areas and generates revenue in millions of birr through collecting funds from lease. They also want land development through removal of old investment then substituted by new investment which can support and meet urban planning and development. Without incurring high costs, federal, regional and local governments wants to undertake public sector projects such as road construction, schools, health stations, water and drainage projects and government buildings. However, the gap which is created by municipality official is lack of mutual consent, mutual trust and benefits of peri-urban farmers on one side and other stakeholders (urban dwellers, private investors, government and others development partners) at another side. Compensation which is made for evicted farmers is minimal because they only cover property situated on the expropriated land. However, as interview conducted with the municipality officials suggest that farmers are not interested to accept monetary compensation even in millions birr and resist losing their land.

Land to land compensation: According to Urban Lands Lease Holding Proclamation [16] states that old possession is a plot of land legally acquired before the urban center entered into areas and the leasehold system or a land provided as compensation in kind to persons evicted from old possession. According FDRE, Council of Ministers Regulations [17], article 15 deals with where land used for growing crops or a protected grass or pastoral land is expropriated for public purpose, the possessor of such land shall, as much as possible, be provided with a plot of land capable of serving a similar purpose. This indicates evicted households from their land may get other land as the in kind compensation. So proclamation argued land to land compensation is possible for evicted indigenous farmers as lease proclamation suggests. However, the actual practice shows that mostly compensation is made in cash but infrequent in kind compensation. Even if proclamation suggests land to land compensation and different authors suggested as good mechanism to rehabilitate indigenous evicted farmers, it is seldom practice by different municipalities in Amhara regional state. As interview conducted with municipality

\begin{tabular}{|c|c|c|c|c|c|c|c|}
\hline No. & $\begin{array}{l}\text { Rehabilitation Strategies for evicted } \\
\text { farmers }\end{array}$ & Respondents & Minimum & Maximum & Mean & Std. Deviation & $\begin{array}{l}\text { Pearson coefficient } \\
\text { correlation }\end{array}$ \\
\hline A. & Monetary Compensation & 200 & 1 & 5 & 4.08 & 0.94 & 0.428 \\
\hline B. & Land to Land Compensation & 200 & 1 & 5 & 3.19 & 1.18 & 0.234 \\
\hline C. & Monetary and Land-Land Compensation & 200 & 1 & 5 & 3.42 & 1.14 & 0.296 \\
\hline D. & Income capitalization & 200 & 1 & 5 & 3.64 & 1.02 & 0.365 \\
\hline E. & Temporary residential house after eviction & 200 & 1 & 5 & 3.54 & 1.1 & 0.111 \\
\hline $\mathrm{F}$. & $\begin{array}{l}\text { Provide permanent and sustainable job } \\
\text { opportunity }\end{array}$ & 200 & 1 & 5 & 2.21 & 1.42 & 0.202 \\
\hline \multirow[t]{2}{*}{ G. } & $\begin{array}{l}\text { Provide reasonable, adequate and on-time } \\
\text { training }\end{array}$ & 200 & 1 & 5 & 2.55 & 1.31 & 0.219 \\
\hline & Valid N (list wise) & 200 & & & & & \\
\hline
\end{tabular}

Table 2: Rehabilitation strategies for evicted farmers. 
officials' argued that municipality has own 'land bank'. Land bank is a portion of land which is owned by local government alone through monetary compensation and no claim from rural or urban dwellers. So when portion of land is expropriated from peri-urban farmers, local government has capacity to rehabilitate evicted farmers through land to land compensation from land bank.

Partial monetary and land compensation: According to (FDRE Proclamation No. 455/2005, 2005), art.8, sub-art. 4, an urban landholder whose landholding has been expropriated under this Proclamation shall: (a) be provided with a plot of urban land, the size of which shall be determined by the urban administration, to be used for the construction of a dwelling house; and, (b) Be paid a displacement compensation equivalent to the estimated annual rent of the demolished dwelling house or be allowed to reside, force (charge, for one year in a comparable dwelling house owned by the urban administration). Partial monetary and land compensation is the providing some portion amount of land (give pilot land for each household and each plot of lands for each children of the family) and provide monetary compensation for uncompensated portion of land. Partial monetary and land compensation is rarely practiced in some municipalities. If targeted land is highly demanded by investors/ public for better developmental purpose, local government may provide some amount in monetary compensation (not fully monetary compensation) and provide land to land compensation for in-return of expropriated part of land which is not covered by monetary compensation. Relatively this is a good mechanism to rehabilitate evicted indigenous farmers due to; a) not wholly loss of their land and livelihood, b) monetary compensation which is provided for them helps to re-development of a land in kind compensation which was provided to them, c) helps to protect them from moral and psychological loss, d) helps to protect them from social destructions, and e) reduce regret and grievance of farmers after eviction.

Income capitalization: According to (FDRE Proclamation No. 455/2005, 2005); art. 8, sub-art.1), a rural landholder whose landholding has been permanently expropriate shall, in addition to the compensation payable, it will be paid for them displacement compensation which shall be equivalent to ten times the average annual income he secured during the five years preceding the expropriation of the land provided (art.8, sub-art.1). According to (FDRE Proclamation No. 455/2005, 2005), Where the woreda administration confirms that a substitute land which can be easily ploughed and generate comparable income is available for the land holder, the compensation to be paid under Sub-Articles (1) and (2) of this Article shall only be equivalent to the average annual income secured during the five years preceding the expropriation of the land (ibid, art. 8, sub-art.3). However, the fact on the ground does not fully implement of this article but in exceptional cases. In some cases at some time they pay displacement compensation for evicted farmers in Amhara regional state. However, at other time they only pay monetary compensation for demolished properties. However, as recent practices in all sampled municipality shows the properties that are situated on the land was calculated and then multiplied by ten times in a consideration of future income. Paying income capitalization, specially, covering displacement compensation is the good mechanism to rehabilitate indigenous evicted farmers. This indicates evicted farmers' future survival strategies will be considered in income capitalization mechanism. According to (Amhara Regional State Proclamation No. 133/2006, 2006), the formula of compensation to be paid to the rural land to be expropriated for public service shall be determined by a regulation.
Provide temporary kebele residential house and container for business: The rare rehabilitation practice is also facilitate and provide temporary kebele residential house and provide containers for evicted farmers for maximum of one year. This is temporary rehabilitation mechanism which helps to reduce unnecessary cost of survival strategy, provide temporary shelter, helps to reduce degree of grievance and temporary solutions for economic and social impacts of urbanization on peri-urban farmers. If evicted farmers has only residential house on the expropriated land, they get Kebele house and if they have a business on the area, they will get temporary container house for businesses. The municipality should have encourage and organize them in order to start small and micro enterprises. For that matter containers which are available in different municipalities, can be used to start business and create employment opportunities. As the current practice and experience shows only Dessie municipality rehabilitate evicted farmers through providing temporary residential kebele house and container for business. By considering family size, employment opportunities, social and economic impacts of losing land and future prospective, they provide such compensation mechanism for evicted farmers.

Provide permanent and sustainable job opportunity: The longterm and short term best rehabilitation mechanism of survival strategies for peri-urban evicted farmers are create permanent employment opportunity but rarely practice. Those investments which are undertaken on expropriated land, regardless of owners of investment, should create employment opportunity for evicted indigenous farmers. If the project which is undertaken on expropriated land is public projects, municipality must give high priority for evicted farmers in order to give job opportunities that are created by the projects. If it is private, NGO and cooperative union projects, municipality should have create legal binding agreement in order to provide a job for evicted farmers and should have get high priority.

The best practice that Dessie municipality performed is that those evicted farmers as the result of construction of Wollo University are employing in the university. In Shoa Robbit municipality, those farmers who were evicted from industrial zone are organized in micro and small scale enterprises, use their compensation as source of finance and get containers to start businesses. But only few individuals who were participated on this businesses. However, this is not practiced in others municipalities of Amhara regional state. Generally, regardless of the owners, all evicted farmers who were expropriated from their land should get job opportunities that helps to improve their livelihood, helps to continue their social and economic livelihood, generate permanent income, helps to protect moral and psychological of evicted farmers and helps continue their normal livelihood.

Provide reasonable, adequate and on-time training: As it is identified in the finding of the study, lack of skills, knowledge and experience, poor saving habits and poor technique of survival strategies are the main challenges on the side of peri-urban evicted farmers as experience of sampled municipalities and current practice suggests. Conducted interview and profile of respondents suggested that majority of our peri-urban farmers are un-educated, unskilled and unexperienced to compete for job opportunities, promote saving, adopt new way of life, use different machineries and equipment and technologies. So they need training in different fields of professions like in business (income generation), techniques to use machineries and sophisticated equipment, to improve saving habits and reduce unnecessary costs, to compete for job opportunities, methods and techniques to start their own businesses, to transform their economy and activities from agriculture to non-agriculture, methods and 
techniques to use new technologies and to adopt the new way of life and future survival strategies of peri-urban evicted farmers who were expropriated from their land. Starting activities concerning training are done in Kombolcha municipality, however, not cover all evicted households. For example, in 2008 more than 800 households' farmers were evicted from their land but only 257 evicted households were get training. But this rehabilitation mechanism was not practiced in others sampled municipalities of Amhara regional state.

\section{Complaints and grievance handling of peri-urban evicted farmers}

According to (FDRE Proclamation No. 455/2005, 2005) Art 11, Rural areas and in an urban center where an administrative organ to hear grievances related to urban landholding is not yet established, a complaint relating to the amount of compensation shall be submitted to the regular court having jurisdiction. The proclamation presents its limitation and there is no administrative organ that can hear and assess the grievances of evicted farmers. Due to this fact, in most municipalities evicted farmers are directly communicating with municipality mayor. Judges are interpreter of laws but not consider the grievance from social and economic prospective. They only implement the proclamation and laws which is adopted by governments. So whether peri-urban farmers are satisfied or not, they do not consider but only implement proclamation and laws.

According to (FDRE Proclamation No. 455/2005, 2005), argued that where the holder of an expropriated urban landholding is dissatisfied with the amount of compensation, he may lodge his complaint to the administrative organ established by the urban administration to hear grievances related to urban landholdings. The organ referred to in Sub-Article (2) of this Article shall examine the compliant and give its decision within such short period as specific by directives issued by the region and communicate its decision to the parties in writing, (art. 11, sub-art3). A party dissatisfied with a decision, rendered in accordance with Sub-Article (I) and (3) of this Article may appeal, as may be appropriate, to the regular appellate court or municipal appellate court within 30 days from the date of the decision. The decision of the court shall be final (art. 11, sub-art. 4). An appeal submitted, pursuant to Sub-Article (4) of this Article, by any landholder served with an expropriation order may be admitted only if it is accompanied with a document that proofs the handover of the land to the urban or woreda administration. (art. 11, sub-art. 6). The execution of an expropriation order may not be delayed due to a complaint regarding the amount of compensation. (art. 11, sub-art. 7). According Amhara regional state proclamation No. 133/2006, article 28, expropriation shall be made, based on the information from the Authority, notify it in writing to the land holder at time of expropriation and the amount of compensation to be paid.

Generally, (FDRE Proclamation No. 455/2005, 2005) article 11 and Amhara regional state proclamation No. 133/2006, article 28, deals with the procedures of handling grievances and complaints on treatment of urban and rural dwellers regarding compensation and rehabilitations mechanism. One of the policy and proclamation limitations is on grievance handling mechanism and procedures. This article of proclamation suggested that if farmers are not satisfied with the compensation, they have the right to appeal to woreda/municipality regular court system. The decision of the woreda/municipality court shall be the final decision. If evicted communities are not satisfied by the court decisions, they have no right to appeal to high court. Their rights to appeal are limited to municipality/woreda court. However, in Shoa Robbit municipality there is Free to appeal up to regional government and courts. Even there was a case in which Amhara regional states interfere and handle the grievance of peri-urban farmers. Grievance hearing and handling was done by committees under the guidance of municipality mayor. Property valuation and grievance handling Committees in Shoa Robbit municipality includes commerce specialist, service sector representative, finance officer, agricultural officer, and rural development officer under the supervisor of municipality mayor officer. As an interview conducted with all sampled municipality officials reveal that grievance hearing and appealing to high court is open up to regional even up to federal government. However, questionnaires collected from evicted farmers suggest that they have un-responded grievances concerning means of treatment and complaints handling mechanism. Even if they have a number of grievances on compensation and rehabilitation mechanism, when they complaint, they do not get satisfied decisions. This creates peri-urban evicted farmers to live in hopeless and extreme poverty.

\section{The role and practice of local government on land expropriation}

As to (FDRE Proclamation No. 455/2005, 2005) Art. 3 argued that woreda or an urban administration shall, upon payment in advance of compensation in accordance with this Proclamation, have the power to expropriate rural or urban landholdings for public purpose where it believes that it should be used for a better development project to be carried out by public entities, private investors, cooperative societies or other organs, or where' such expropriation has been decided by the appropriate higher regional or federal government organ for the same purposes. According to FDRE Proclamation No. 455/2005, 2005, art. 13, Administrations and Urban With respect to the, implementation of this Proclamation woreda and urban administration" shall have the responsibilities and duties to Payer cause the payment of compensation to holders of expropriated land in accordance with this Proclamation, and provide them with rehabilitation support to the extent possible (sub-art. 1). This proclamation argued that based on compensation given for households, expropriation and eviction process of households from their land will begin.

The current practice of expropriation in all sampled municipalities shows that they do not follow standardized procedures and not through mutual consent. The compensation mechanism which is allotted and given for households is in a monetary payment. Through public consultation, all targeted households who will be expropriated will be informed in advance before expropriation begins. After they inform through public consultation, they proceed to property valuation which is situated on the land. Then they provide that monetary payment for target households. If refuse to accept that payment they deposit that amount in commercial bank of Ethiopia and proceed to demolishing the property which is situated on the land. If they that households claim not to demolish, they arrest and take legal measures. This argued that if households have no property on the land they have no right to claim on the land because land is the public property. So debating issue is the fate of livelihood of those indigenous evicted farmers. If the land is covered by crop and other agricultural products, through replacement cost methods value and annual income of property situated on the land will be calculated and multiplied by ten times then paid to evicted households. This is done by local governments (municipality or woreda administration officials).

\section{Conclusion and Practical Implications}

Based on analyzed data, the following conclusions and practical implications were made. 


\section{Conclusion}

Urbanization and urban development in Ethiopia is the complex process, in which, majority of peri-urban farmers are net losers and few private investors and urban dwellers are net winners. Policies and proclamations concerning expropriation process and rehabilitation mechanism of peri-urban farmers were amended at different time. However, it did no touch the core problems of peri-urban farmers and did not protect the interest of those farmers. Even, implementation policies and proclamation is also poor. During urban planning and designing, concerned stakeholder (peri-urban farmers) is not participatory. Peri-urban farmers' economic livelihood and their survival strategies are not considered while designing urban plans and programs. Due to this fact, urban programs and practice are neither participatory nor integrative process that negatively affects the economic livelihood of peri-urban farming communities.

Land Expropriation process in Ethiopia seems to be emotional activities and its implementation is supported by coercive police force and mostly resulted in a crises. This indicates preconditions and necessarily conditions before land expropriation were not carried out. Reasonable and on-time public consultations were not done. If there is a good public consultation on-time, peri-urban farmers will take necessarily measures and self-preparation will be made. So they will ready to take any risk associated with land expropriation. Not only public consultation, municipality should work on grievance handling mechanism. When societies repeatedly submit complaints without justified and reasonable response, they will be hopeless, mistrust and endanger the image of government. Rehabilitation mechanism that most municipalities used were considered as neither fully neither implements policies nor satisfy the interest of peri-urban farmers. They did no use similar and standardized procedures for the practice. Mostly, they only pay monetary compensation and income capitalization as seldom practice. All municipalities are not doing enough on rehabilitation and future survival strategies, mechanism to reduce and handle grievances, providing sufficient and updated information, capacity building and mutual benefits and collaboration with peri-urban farmers.

Generally, economic livelihood of peri-urban farmers are overlooked and they are forgotten part of communities by municipalities. Their complaints and grievances are not properly handled and solution mechanism is not properly designed. Eviction through expropriation of land without considering their future survival strategies, only through monetary compensation, is highly practiced in Amhara regional state. If the livelihood of those farming communities is not considered by local government, no one can follow and support those farmers.

\section{Practical implications}

Based on analyzed data and conclusion, the following practical implications were suggested;

Proper rehabilitation strategy for peri-urban farmers are combination of partial monetary and land to land compensation, income capitalization, provide permanent and sustainable job opportunity and provide reasonable training. Current Rehabilitation mechanism and procedure is not a guarantee for future survival strategies of peri-urban farmers.

The land expropriation process should follow standardized and legally justified procedure. Municipality should notify targeted periurban farmers in advance, and then public consultation, then mutual agreement then proceeds to property valuation. Finally, provide training and rehabilitate evicted farmers.

Proper grievance handling mechanism should be applied. It should include group of experts from judges, economic impact assessor, planners and designers, farmers' representative, expert of valuation of property. This team should include at least five effective and qualified experts from each municipality who can properly assess, consider and make a decision concerning rehabilitation practice and grievance handling of evicted peri-urban farmers.

Municipality should provide necessary support (training, finance and improve capacity), provide updated information, create enabling environment through organizing and start business in small and micro enterprise, provide containers and make them functional and continue their livelihood than before.

\section{References}

1. Dayong N (2004) Several Acute Issues in China's Urban Planning.

2. Rakodi C (1997) Global Forces, Urban Change and Urban Management in Africa, Growth and Management of its Large Cities. Tokyo. The United Nation University Press.

3. Adem K, Fenta M (2012) Urban Expansion and the Neighborhoods: The Case of Bishoftu Town, East Shewa Zone, Oromia Regional State, Ethiopia. Addis Ababa University.

4. DFID (2008) Adoption and impact of livelihood activities on community members in the Kumasi Peri-Urban Interface R8090, Centre for the Development of People (CEDEP). Kumasi, Ghana, p: 78.

5. Bhadra, Dipasis, Salazar PB, Antonio (1993) Urbanization, Agricultural development and Land allocation. World Bank discussion paper.

6. Feleke (1999) Impact of Urban 'Development' on Peasant community in Ethiopia: the case for Yeka Tafo, MA Thesis. Addis Ababa University.

7. OUPI (2008) Structural Plan of Sebata Town Document Prepared by Oromia Urban Planning Institute. Addis Ababa.

8. Fayera (2005) Urban Expansion and Livelihood of the Peri-urban Agricultural Community: the case of Addis Ababa, MA Thesis, Addis Ababa University.

9. Amhara Regional State Proclamation No. 133/2006 (2006) The Revised Amhara National Regional State Rural Land Administration and Use Proclamation. Zikre Hig, Bahir Dar.

10. FDRE Proclamation No. $455 / 2005$ (2005) A Proclamation to Provide for the Expropriation of Land Hodings for Public Purpose and Payment of Compensation. Proclamation No. 455/2005. Addis Ababa: Federal Democratic Republic of Ethiopia (FDRE). Federal Negarit Gazeta.

11. FDRE (2005) Rural Land Administration and Land Use Proclamation Proclamation No. 456/2005. Year 11, No. 44. Negarit Gazeta.

12. Mougeot $L$ (2000) Urban agriculture: definition, presence, potentials and risks. Growing cities, growing food, urban agriculture on the policy agenda, DSE Feldafing, pp: 1-42.

13. Ambaye DW (2009) Land Valuation for Expropriation in Ethiopia: Valuation Methods and Adequacy of Compensation, Ethiopia $7^{\text {th }}$ FIG Regional Conference Spatial Data Serving People. Land Governance and the Environment - Building the Capacity Hanoi, Vietnam.

14. Alemu B (2013) Expropriation, valuation and compensation practice in Ethiopia: The case of Bahir Dar city and surrounding. Property Management 31 132-158.

15. FDRE (2007) Councils of Ministers Regulation on the payment of properties situated on the landholding expropriated for public purposes, Addis Ababa: Ethiopia. Negaret Gazeta.

16. FDRE (2011) Urban Lands Lease Holding Proclamation, Proclamation No. 721/2011. No. 4. Negarit Gazeta.

17. FDRE Council of Ministers Regulations No. 135/2007, 2007) Council of Ministers Regulations On The Payment of Compensation For Property Situated On Landholdings Expropriated For Public Purposes. 